\title{
Multiple foraminal compression in a child with sialidosis type 2
}

Hans-Ulrich Bender, MD, Ingo Borggraefe, MD, Eva Coppenrath, MD, and Esther Maria Maier, MD

Neurology ${ }^{\circledR}$ 2019;93:168-169. doi:10.1212/WNL.0000000000007835

Figure Spinal MRI in sialidosis type 2
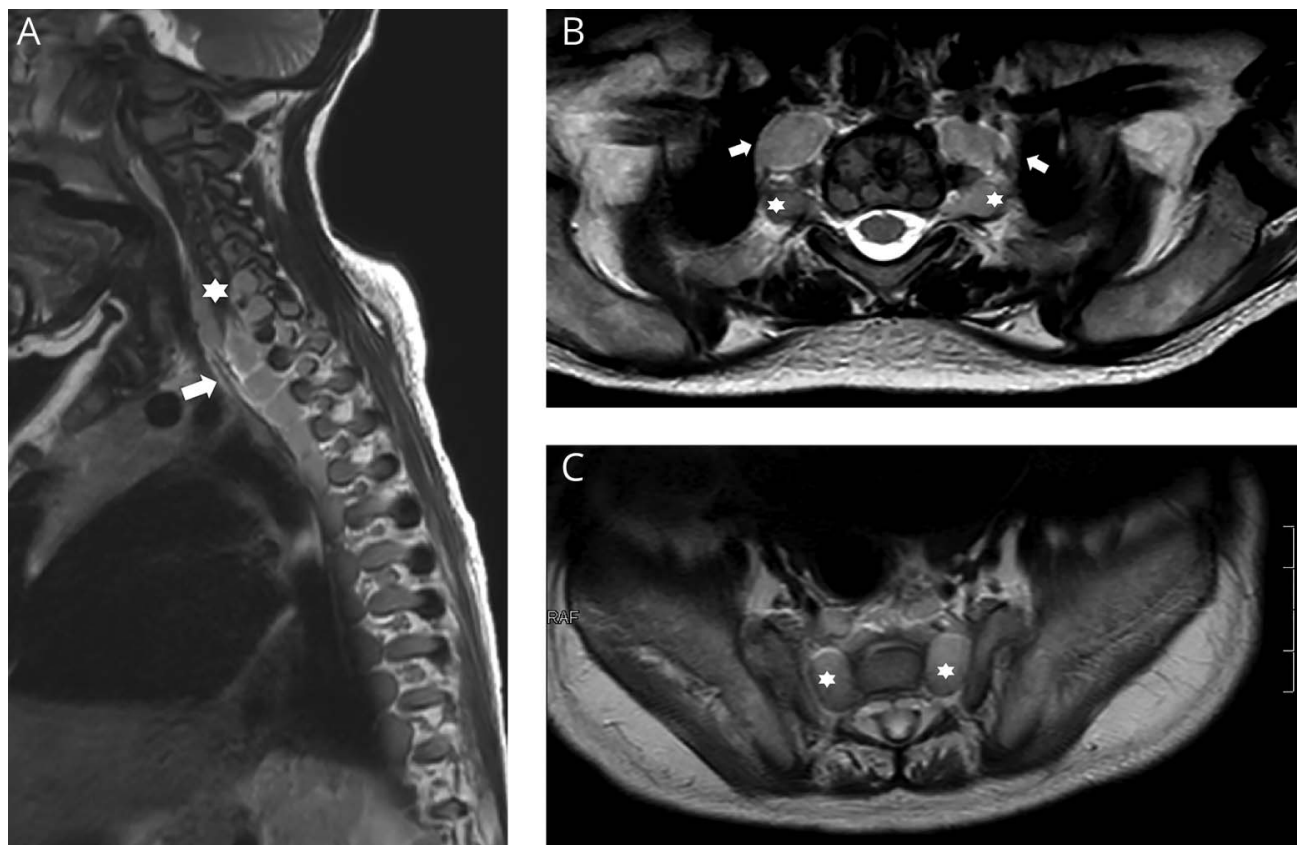

T2-weighted (A) sagittal and $(B, C)$ transversal MRI: enlarged ganglia, neuroforamina (asterisks); thickened prevertebral ganglia (arrows). (B) Thoracic and (C) sacral spine.

A 7-year-old girl with infantile sialidosis type 2 presented with progressive tetraparesis. MRI of the spine showed enlarged nerve roots and paravertebral ganglia of the entire spine (figure). Neuroblastoma and neurofibromatosis were excluded. Six months later, neuropathic pain of arms and legs and allodynia appeared; treatment with gabapentin $(50 \mathrm{mg} / \mathrm{kg}$ body weight $)$ was successful.

Intracellular deposits in sialidosis consisting of sialylated oligosaccharides and glycolipids are present in many tissues. ${ }^{1,2}$ This unusual presentation of multiple foraminal compression is most likely due to deposits in the spinal roots and paravertebral ganglia in this patient with sialidosis type 2 .

\section{Author contributions}

H.U. Bender: drafting/revising the manuscript, data acquisition, study concept or design, analysis or interpretation of data, accepts responsibility for conduct of research and final approval. I. Borggraefe: data acquisition, accepts responsibility for conduct of research and final approval, acquisition of data. E. Coppenrath: data acquisition, analysis or interpretation of data,
Correspondence

Dr. Bender

HansUlrich.Bender@

med.uni-muenchen.de

From the Center for Pediatric Palliative Care (H.-U.B.), Department of Pediatric Neurology (I.B.), and Department of Inborn Errors of Metabolism (E.M.M.), Dr. von Hauner Children's Hospital, and Institute for Diagnostic and Clinical Radiology (E.C.), University of Munich Medical Center, Ludwig-Maximilians-University, Germany.

Go to Neurology.org/N for full disclosures. Funding information and disclosures deemed relevant by the authors, if any, are provided at the end of the article. 
accepts responsibility for conduct of research and final approval, contribution of vital reagents/tools/patients, acquisition of data. E.M. Maier: drafting/revising the manuscript, data acquisition, analysis or interpretation of data, accepts responsibility for conduct of research and final approval.

\section{Study funding}

No targeted funding reported.

\section{Disclosure}

The authors report no disclosures relevant to the manuscript. Go to Neurology.org/N for full disclosures.

\section{References}

1. D'Azzo A, Machado E, Annunziata I. Pathogenesis, emerging therapeutic targets and treatment in sialidosis. Expert Opin Orphan Drugs 2015;3:491-504.

2. Faerber EN, Poussaint TY. Magnetic resonance of metabolic and degenerative diseases in children. Top Magn Reson imaging 2002;13:3-21.

\section{Subspecialty Alerts by E-mail!}

Customize your online journal experience by signing up for e-mail alerts related to your subspecialty or area of interest. Access this free service by clicking on the "My Alerts" link on the home page. An extensive list of subspecialties, methods, and study design choices will be available for you to choose from-allowing you priority alerts to cutting-edge research in your field!

\section{The AAN is Fighting for You!}

In the midst of rapid changes in health care policy, the AAN has your back. From actively lobbying members of Congress to meeting with regulators to underscore the value of neurology and your services to your patients, the Academy is forcefully countering any threats to your profession and patient access to care. Learn more at AAN.com/policy-and-guidelines/advocacy, read the bimonthly Capitol Hill Report and monthly $A A N n e w s^{\circledR}$ member magazine, and respond to Advocacy Action Alert emails when we invite you to share your voice with Congress.

\section{Visit the Neurology ${ }^{\circledast}$ Resident \& Fellow Website}

Click on Residents \& Fellows tab at Neurology.org.

Now offering:

- Neurology ${ }^{\circledR}$ Resident \& Fellow Editorial team information

- "Search by subcategory" option

- E-pearl of the Week

- RSS Feeds

- Direct links to Continuum ${ }^{\circledR}$, Career Planning, and AAN Resident \& Fellow pages

- Recently published Resident \& Fellow articles

- Podcast descriptions

f Find Neurology ${ }^{\circledR}$ Residents \& Fellows Section on Facebook: http://tinyurl.com/o8ahsys

Follow Neurology ${ }^{\circledR}$ on Twitter: http://twitter.com/GreenJournal 


\section{Neurology}

Multiple foraminal compression in a child with sialidosis type 2

Hans-Ulrich Bender, Ingo Borggraefe, Eva Coppenrath, et al.

Neurology 2019;93;168-169

DOI 10.1212/WNL.0000000000007835

This information is current as of July 22, 2019

Updated Information \&

Services

\section{References}

Subspecialty Collections

Permissions \& Licensing

Reprints including high resolution figures, can be found at: http://n.neurology.org/content/93/4/168.full

This article cites 2 articles, 0 of which you can access for free at: http://n.neurology.org/content/93/4/168.full\#ref-list-1

This article, along with others on similar topics, appears in the following collection(s): All Spinal Cord

http://n.neurology.org/cgi/collection/all_spinal_cord Lipidoses

http://n.neurology.org/cgi/collection/lipidoses

Metabolic disease (inherited)

http://n.neurology.org/cgi/collection/metabolic_disease_inherited

MRI

http://n.neurology.org/cgi/collection/mri

Neuropathic pain

http://n.neurology.org/cgi/collection/neuropathic_pain

Information about reproducing this article in parts (figures,tables) or in its entirety can be found online at:

http://www.neurology.org/about/about_the_journal\#permissions

Information about ordering reprints can be found online:

http://n.neurology.org/subscribers/advertise

Neurology $\AA$ is the official journal of the American Academy of Neurology. Published continuously since 1951, it is now a weekly with 48 issues per year. Copyright (C 2019 American Academy of Neurology. All rights reserved. Print ISSN:

0028-3878. Online ISSN: 1526-632X.

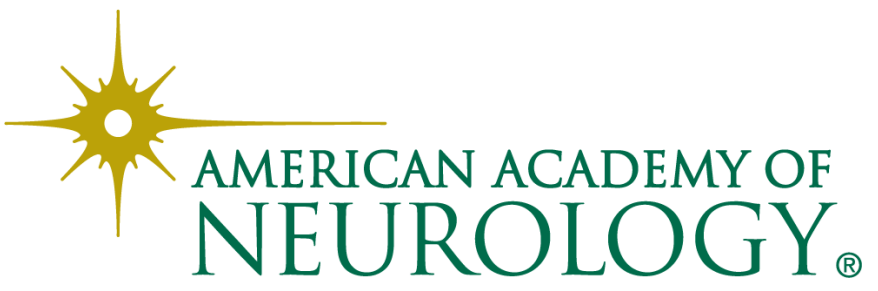

